\title{
Susceptibility to Phytophthora Cinnamomi of two Grapevine Rootstock Clones after Thermotherapy
}

\author{
P. G. MARAIS AND M. J. HATTINGH
}

Respectively from the Viticultural and Oenological Research Institute, Private Bag X5026, Stellenbosch 7600, South Africa and Department of Plant Pathology, University of Stellenbosch, Stellenbosch 7600, South Africa.

Part of a thesis submitted by the first author to the University of Stellenbosch for the Ph.D.(Agric) degree.

Submitted for publication: March 1984

Accepted for publication: July 1984

\begin{abstract}
The grapevine rootstocks 99 Richter clone 1/30/1H74 infected with grapevine fleck and leafroll and 99 Richter Prosperi Super subclone 5 infected with stem pitting and leafroll were more susceptible to Phytophthora cinnamomi without treatment than after heat treatment to eliminate viruses. Recent field observations by various local workers (unpublished) and claims by local growers suggested that 99 Richer (Vitis berlandieri $P$. x V rupestris $S$.) grapevine rootstock material previously subjected to thermotherapy is more susceptible to Phytophthora cinnamomi Rands than untreated material. This contribution provides data on the effect of thermotherapy on the susceptibility of two 99 Richter rootstock clones to P. cinnamomi.
\end{abstract}

\section{MATERIALS AND METHODS}

Two virus-infected clones were used: 99 Richter clone 1/30/1H74 infected with leafroll and grapevine fleck viruses and 99 Richter Prosperi Super subclone 5 infected with leafroll and stem pitting viruses. After thermotherapy $\left(38^{\circ} \mathrm{C}\right.$ for $c a 150 \mathrm{~d}$ ) and indexing on a standard range of indicators, both treated clones indexed free of these viruses (D. J. Engelbrecht, Plant Protection Research Institute, Stellenbosch, personal communication).

Fifty plants each of treated and untreated material were planted in $30 \mathrm{~cm}$ free-draining clay pots containing a sterilised potting mixture. Half the pots of each treatment batch were inoculated with $P$. cinnamomi by adding a homogenized preparation of a 7 to 10 -d-old potato dextrose agar (PDA) culture of $P$. cinnamomi into each of four holes in the soil around the vines. The pots were randomized in a glasshouse at $25^{\circ} \mathrm{C} \pm 5{ }^{\circ} \mathrm{C}$ and watered weekly. Pathogenicity was evaluated 12 weeks after inoculation by comparing the mass of roots and shoots of inoculated and uninoculated vines, by counting the number of dead plants and by making root isolations from living plants on PDA.

\section{RESULTS AND DISCUSSION}

A two-way analysis of variance was applied to the data given in Table 1. The uninoculated treatments (both clones) had no dead vines or vines with infected roots and significantly higher root mass and shoot mass than the inoculated treatments. The inoculated treatments

TABLE 1

Effect of Phytophthora cinnamomi on virus-infected grapevine rootstock clones ${ }^{\mathrm{a}}$ subjected to thermotherapy ${ }^{\mathrm{b}}$

\begin{tabular}{|c|c|c|c|c|c|c|}
\hline Rootstock & Treatment & & $\begin{array}{l}\text { Dead vines } \\
\text { (no) }\end{array}$ & $\begin{array}{l}\text { Living vines with } \\
\text { infected roots } \\
\text { (no) }\end{array}$ & $\begin{array}{l}\text { Root mass } \\
(\mathrm{g})\end{array}$ & $\begin{array}{l}\text { Shoot mass } \\
\text { (g) }\end{array}$ \\
\hline \multirow{3}{*}{$\begin{array}{l}99 \text { Richter clone } \\
1 / 30 / 1 \mathrm{H} 74\end{array}$} & \multirow{3}{*}{ Heat-treated } & Inoculated & 2 & 4 & 2,47 & 1,41 \\
\hline & & Uninoculated & 0 & 0 & 3,23 & 2,59 \\
\hline & & Inoculated & 9 & 6 & 1,82 & 1,14 \\
\hline \multirow{5}{*}{$\begin{array}{l}99 \text { Richter Prosperi } \\
\text { Super }\end{array}$} & \multirow{2}{*}{ Control } & Uninoculated & 0 & 0 & 3,22 & 2,41 \\
\hline & & Inoculated & 3 & 4 & 2,42 & 2,46 \\
\hline & \multirow[t]{2}{*}{ Heat-treated } & Uninoculated & 0 & 0 & 370 & 346 \\
\hline & & Inoculated & 8 & 9 & 2,01 & 2,22 \\
\hline & Control & Uninoculated & 0 & 0 & 3,61 & 3,38 \\
\hline \multirow{2}{*}{\multicolumn{3}{|c|}{$\begin{array}{l}D \text { value }(P=0,05) \text { for } 99 \text { Richter }(1 / 30 / 1 \mathrm{H} 74) \\
D \text { value }(P=0,05) \text { for } 99 \text { Richter Prosperi Super }\end{array}$}} & - & - & 0,64 & 0,25 \\
\hline & & & - & - & 0,53 & 0,20 \\
\hline
\end{tabular}

${ }^{a}$ Fifty rootstocks per treatment

b $38^{\circ} \mathrm{C}$ for $\mathrm{ca} 150$ days. 
(both clones) had fewer dead heat-treated than untreat vines and also fewer heat-treated vines with infected roots. The shoot mass of inoculated heat-treated vines was also higher than that of inoculated untreated vines. In the case of 99 Richter clone 1/30/1H74 the root mass of inoculated heat-treated vines was significantly higher than that of the inoculated virus-infected material.

The two rootstock clones cured from virus by thermotherapy were less susceptible to $P$. cinnamomi than the same rootstock clones infected with the respective viruses. This agrees with findings of workers on other crops. Thus Russell (1966) with sugar beet, and Bovey (1963) and Campbell (1969) with apples, found that infection with virus increased the susceptibility of plants to several fungal pathogens.

Under the existing local plant improvement scheme grapevine rootstock and scion material are subjected to thermotherapy and subsequent meristem shoot tip culture to free them from known harmful viruses. The findings in the present study give added motivation for the scheme.

\section{LITERATURE CITED}

BOVEY, R., 1963. Observations and experiments on apple proliferation disease. Phytopath. Medit. 2, 111-114.

CAMPBELL, A. I., 1969. The effect of some apple viruses on the susceptibility of two clonal rootstocks to collar rot caused by Phtophthora cactorum. J. hort. Sci. 44, 69-73.

RUSSELL, G. E., 1966. The control of Alternaria species on leaves of sugar beet infected with yellowing viruses. Ann. appl. Biol. 57, 425-434. 